\title{
ELK CALF “HIDES” UNDERWATER
}

\section{WILLIAM J. WALLEY, 222 Bossons Avenue, Dauphin, Manitoba. R7N 0R2}

Whitewater Lake is located in the central sector of Riding Mountain National Park, Manitoba. This wilderness lake area, accessible to the public only by foot or non-motorized vehicle, is a mosaic of mixed spruce-poplar forest with dense growths of hazelnut (Corylus sp.) and small lowland swamps dominated by sedge (Carex sp.). A few open grassy meadows range from 0.5 to about six ha in area. The region is prime habitat for the American Elk (Cervus elaphus manitobensis) and is a principal calving locality for the species. A beaver dam at the lake's outlet, built in the mid1970s, raised the water level causing flooding of the lake's two islands and lowland woods adjacent to the lake. The islands are used by the elk for refuge from predators such as wolves (Canis lupus) and bears (Ursus americanus). With the park boundary over five $\mathrm{km}$ south of the lake, no human habitation exists for a least that distance.

On the morning of 31 May 1975, my party of three was hiking eastward along the shore of a wooded promontory when flood waters forced us to detour inland. As we followed the edge of these waters southward, we found an elk calf, estimated to be only a few days old, beside a shrub less than $.25 \mathrm{~m}$ from the water. After a few seconds, it suddenly lunged forward bleating and dropped into the calm, clear water about six m away. Its head was held above the surface with its back exposed. Anticipating that the cow would respond to the calf's bleats and not wanting to interfere further, we left.

About 20 minutes later, I returned to the site to retrieve an item of equipment. To my amazement, the elk was still in the water, this time with its head submerged and only the top of its back ex- posed. As I watched, it lifted its head, breathed and resubmerged. The following day, 1 June, the calf was gone. There was no evidence the animal perished or was attacked by a predator. Presumably, it was led off by the cow.

According to L.N. Carbyn, Canadian Wildlife Service (pers. comm.), who is well versed on the life history of the American Elk, this behaviour had not previously been reported. W. B. Preston of the Manitoba Museum of Man and Nature (pers. comm.) relates two similar incidents involving Columbian Blacktail Deer (Odocoileus hemionus columbianus) fawns on Vancouver Island in the late 1950s. In one instance, Preston had been chasing a fawn in order to tag it and obtain weight and measurement data. It was running along a logging road and suddenly dropped and "froze." It had happened to land in a roadside ditch full of water and its head was submerged. In the other incident, the fawn happened to drop into a mud puddle on a logging road. Preston points out that when very young, fawns tend to drop and "freeze" where they are, at any sign of danger. When they are older, they may run first and then drop, perhaps after becoming fatigued, he suggests.

Geist makes no mention of elk calves utilizing water in which to hide. ${ }^{1}$ However, he stated that if a predator is close, bolting from its hiding place may permit a calf to hide again suddenly, providing it can put a visual barrier between itself and the predator. Could this calf have perceived the water as such a barrier?

It seems highly unlikely that the calf ran toward the water to hide in it. Since its observers were on its west side, it certainly ran away from them eastward 
which happened to be into the water, where it dropped and froze instinctively, albeit with its head up. The adaptive value of freezing in this situation would obviously be lost by the up and own movement of the animal's head. It is an example of an animal negating the adaptive adaptive advantage of freezing in adjusting to an unnatural element in which to breathe - water.

\section{Acknowledgements}

Appreciation is extended to Dr. William B.V. Preston, Manitoba Museum of Man and Nature, Winnipeg, and Dr. L.N. Carbyn, Canadian Wildlife Service, Edmonton, for their remarks and information.

1. GEIST, VALERIUS. 1982. in Thomas, J.W. and D.E. Toweill. Elk of North America ecology and management. Stackpole Books, Harrisburg, Pa. 698 pp.: p. 238.

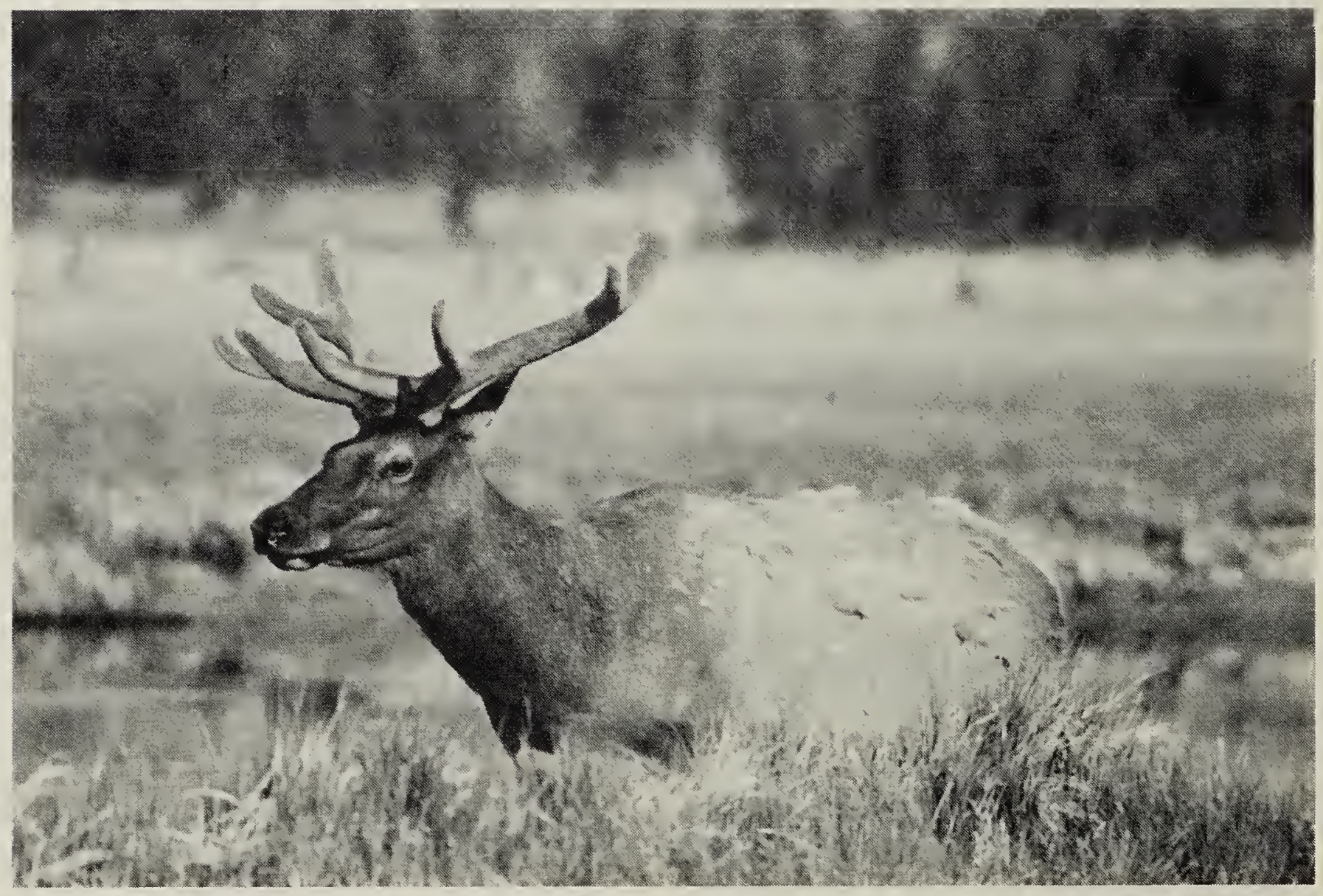

Elk.

Wayne Lynch 